Teïchispira, a New

Early Ordovician

Gastropod Genus

GEOLOGICAL SURVEY PROFESSIONAL PAPER 613-B

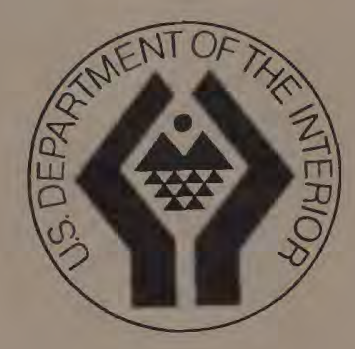



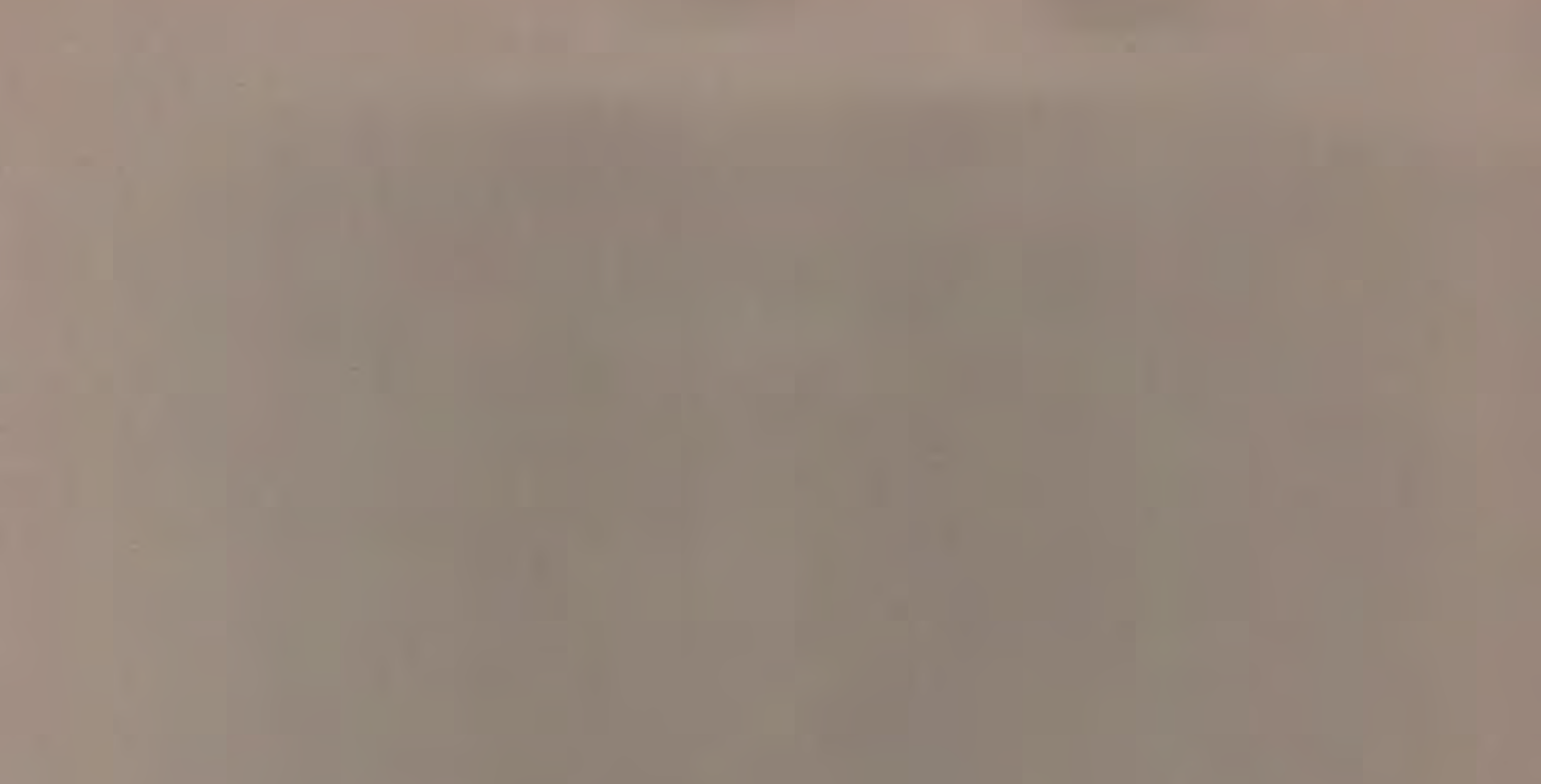
Teïchispira, a New

Early Ordovician

Gastropod Genus

By ELLIS L. YOCHELSON and CLIVE R. JONES

C O N TR I B U T I O N S TO PALEO N T O L O G Y

GEOLOGICAL SURVEY PROFESIONAL PAPER 613-B

Description of an unusual macluritacean

occurring in Malaysia and North America

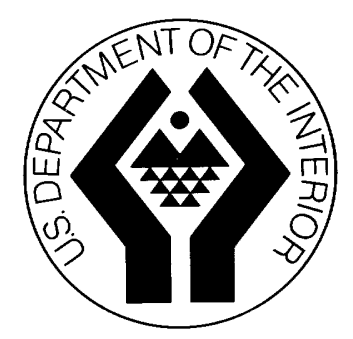

UNITED STATES GOVERNMENT PRINTING OFFICE, WASHINGTON : 1968 
UNITED STATES DEPARTMENT OF THE INTERIOR

STEWART L. UDALL, Secretary

GEOLOGIGAL SURVEY

William T. Pecora, Director

For sale by the Superintendent of Documents, U.S. Government Printing Office

Washington, D.C. 20402 - Price 45 cents (paper cover) 


\section{CONTENTS}

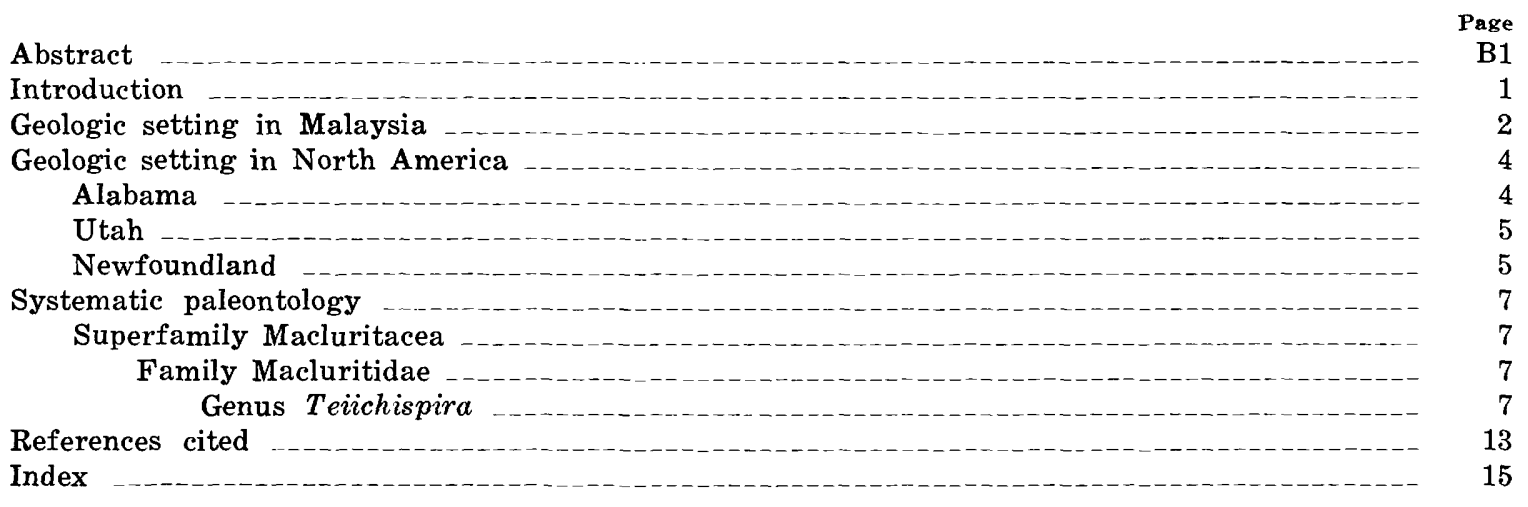

\section{ILLUSTRATIONS}

[Plates follow index]

PLATE 1. Teiichispira? sylpha (Billings) and T. kobayashi Yochelson and Jones.

2. Teiichispira rossi Yochelson and Jones, T. odenvillensis (Butts), and opercula of unnamed macluritaceans.

FigURE 1. Map of northwest Malaysia and southwest Thailand showing distribution of the Setul Formation and localities at which gastropod opercula have been found

Page B3

2. Generalized outer whorl face profiles of some macluritaceans
3. Sketches of the opercular attachment surface of Teiichispira odenvillensis and T. rossi 

CONTRIBUTIONS TO PALEONTOLOGY

\title{
TEIICHISPIRA, A NEW EARLY ORDOVICIAN GASTROPOD GENUS
}

\author{
By Ellis L. Yochelson and Clive R. Jones
}

\begin{abstract}
The new macluritacean genus Teiichispira is characterized in part by an elongate horn-shaped operculum, having a fibrous texture when weathered. The type species Teiichispira kobayashi is widespread in the Setul Formation of northwest Malaysia. A congeneric operculum has been described from the Odenville Limestone of Alabama as Maclurea? odenvillensis. Another new species, T. rossi, known only from its operculum occurs in Utah. Maclurea sylpha Billings, from Newfoundland, is tentatively placed in this genus; no operculum is known to be associated with the species at this time, but generically similar, though specifically indeterminate, fibrous opercula also occur in Newfoundland. Several groups of fossils suggest a very late Early Ordovician age for the type species, as well as for the species from other localities. Opercula of Teiichispira may be potentially useful for dating rocks of latest Early Ordovician age because of their widespread, though scattered, distribution and because they are readily identified from even fragmentary specimens. Other shapes of opercula, not formally named, show the wide diversity to be found within the family.
\end{abstract}

\section{INTRODUCTION}

A curious curved fossil, characterized by a fibrous texture which is particularly conspicuous when silicified, was found repeatedly by Clive Jones while mapping the Setul Formation in northwest Malaysia. Specimens submitted by the Geological Survey of Malaysia in 1964 were determined by E. L. Yochelson to be gastropod opercula. Shortly thereafter, in 1965, a large collection of silicified fossils was made by Arthur J. Boucot, California Institute of Technology, from a limestone of the Setul Formation which crops out at the south point of Pulau (or island) Langgun, Langkawi Islands, Malaysia; at low tide, this area is a peninsula and is locally named Pulau Tikus. This collection provided significant data on the operculum and the shell with which it was associated. Subsequently, much additional material was collected from this outcrop by Richard Jones of Sungei Raya Estate, Pulau Langkawi. These two collections are housed at the U.S. National Museum.
The shell and operculum from the Setul Formation are unique and deserve generic status. The fauna of the Setul Formation in northwest Malaysia was described by Kobayashi (1959), but this shell was poorly represented in those collections and some of his material was obtained from beds of slightly younger age.

The Malaysian material, in turn, suggested affinities with certain North American specimens. T'e peculiar operculum is strikingly similar to Maclurea? odenvillensis from the Odenville Limestone of Alabama, a species heretofore known only from its operculum. Another species, still known only from its operculum, was collected by R. J. Ross, Jr., U.S. Geological Survey, from the Garden City Formation of Utah. At least one Early Ordovician species, described from Newfoundland but known only from its shell, may be congeneric.

The peculiar operculum provides a means of readily distinguishing one group of related forms within the complex or macluritacean gastropods. This new genus may be stratigraphically significant, for at all localities where it occurs, other fossils indicate a late to latest Early Ordovician age. The interest in correlation is enhanced because occurrences of the operculum in Alabama and Malaysia are separated by half the circumference of the earth.

The original collections from Malaysia were made by Clive Jones while employed by the Geological Survey of Malaysia and we are indebted to the Director of the Geological Survey of Malaysia for his kind permission to publish details relevant to these fossils. Without the further collections made by Arthur J. Boucot and Richard Jones, this study could not have been pursued. In addition, acknowledgment is given to Charles W. Cressler, U.S. Geological Survey, who guided Yochelson to the type 
locality of the Odenville Limestone and R. J. Ross, Jr., who directed our attention to the material from northern Utah.

Thomas E. Bolton, Geological Survey of Canada, kindly permitted the study of types and other specimens under his care. Harry E. Whittington, Cambridge University, lent specimens from Newfoundland. Rousseau H. Flower, New Mexico Bureau of Mines and Mineral Resources, and Lehi Hintze, Brigham Young University, lent supplementary material from Utah.

\section{GEOLOGIC SETTING IN MALAYSIA}

The Setul Formation is over 5,000 feet thick and consists almost entirely of complexly folded and faulted limestone. Field investigations show no evidence of unconformities within this great thickness, and presumably the sequence represents virtually uninterrupted deposition on the shelf of an ancient geosyncline. The basal limestone of the Setul conformably overlies deltaic sandstone of Late Cambrian age and has yielded only nautiloid cephalopods belonging to the Early Ordovician genus Robsonoceras or an allied genus. These lower beds pass upward into limestones containing a more diversified nautiloid and gastropod fauna; the peculiar operculum mentioned above is common in the middle part of the Setul Formation in the Langkawi Islands and the State of Perlis (Jones and others, 1966, p. 312). The shelly strata are overlain by sparsely fossiliferous limestones that include lenses of Lower Silurian to Lower Devonian graptolitebearing shale.

The silicified fossil-bearing strata at the Pulau Langgun locality are at a moderately low stratigraphic level in the shelly limestone of the Setul Formation. Evidence from the fossil assemblage as a whole suggests a late Early Ordovician age for this outcrop. Although the isolated opercula collected in other parts of northwest Malaysia seem to persist through strata lying many hundreds of feet above the beds at the south point of Pulau Langgun, there is no other faunal evidence to suggest a younger Ordovician age. Further fieldwork may indicate that the opercula are restricted to a narrow stratigraphic interval.

Localities at which opercula have been found by Clive Jones in northwest Malaysia are shown in figure 1. In addition, one fragmentary specimen was collected some years ago in peninsular Thailand by the Thai Geological Survey. The locality for this specimen is given as Khuan Phanon Chuak near Ronphiboon, in Nakorn Sithamaret Province, 120 miles north of the Malaysian localities.
Kobayashi (1959) has described some of the fossils from the Setul Formation of the Langkawi Islands. He had about 15 isolated gastropod specimens available from four localities ; from the south end of Pulau Langgun he reported:

$$
\begin{aligned}
& \text { Hormotoma (?) spp. indet. } \\
& \text { Helicotoma jonesi Kobayashi } \\
& \text { Palaeomphalus giganteus Kobayashi } \\
& \text { Lesueurilla (?) sp. indet. } \\
& \text { Malayaspira migosa Kobayashi }
\end{aligned}
$$

Kobayashi $(1959$, p. 389) concluded that the Setul Formation "probably correlated to the Neichiashan Formation of Central China and the Vaginatenkalk of the Baltic Region." The thin-bedded limestones of the Neichiashan Formation are richly fossiliferous and were considered by Grabau $(1924$, p. 95$)$ to be equivalent to the Orthoceras Limestone of Sweden, the Vaginatenkalk of the Baltic provincer of the U.S.S.R., and the Black River Group of North America. The Vaginatenkalk is now generally recognized as equivalent to the $B_{I I I}$ series of Estonia and is referred to the Kundan Stage, upnermost Lower Ordovician (Oelandian) of northern Europe (Jaanusson, 1960, p. 301).

About 200 pounds of limestone collected by Arthur J. Boucot and about 500 pounds collected by Richard Jones were dissolved in acid; these yielded abundant representatives of most of the gastropods listed above. No specimens of Helicotoma jonesi have been found in this material and it seems safe to conclude that this species came from another stratum at the locality. Helicotoma is typically a Middle Ordovician genus. Removal of $H$. jonesi from the fauna under consideration further strengthens Kobayashi's correlation.

Relatively few specimens of the species c'escribed as Palaeomphalus giganteus are available. These seem to be more properly referred to Pararaphistoma Vostakova than to Palaeomphalus Koken. Pararaphistoma is characteristic of both $\mathrm{B}_{\mathrm{III}}$ and the Vaginatenkalk; Palaeomphalus occurs in much younger Middle Ordovician beds in the Baltic area.

Kobayashi's report of Hormotoma (?) spp. indet. cannot be commented upon as all our specimens of high-spired gastropods are poorly preserved. The form reported as Lesueurilla(?) sp. indet. is redescribed in detail below.

The most abundant gastropod found at the locality is Malayaspira rugosa Kobayashi (1958, p. 226-227). Kobayashi has remarked on the relationship of Malayaspira to Lecanospira (in the strict sense), a mid-Early Ordovician genus, but he did not compare Malayaspira to the late Early Ordovician subgenus Lecanospira (Barnesella) Bridge and Cloud (1947, p. 545-550). Examination of the primary 


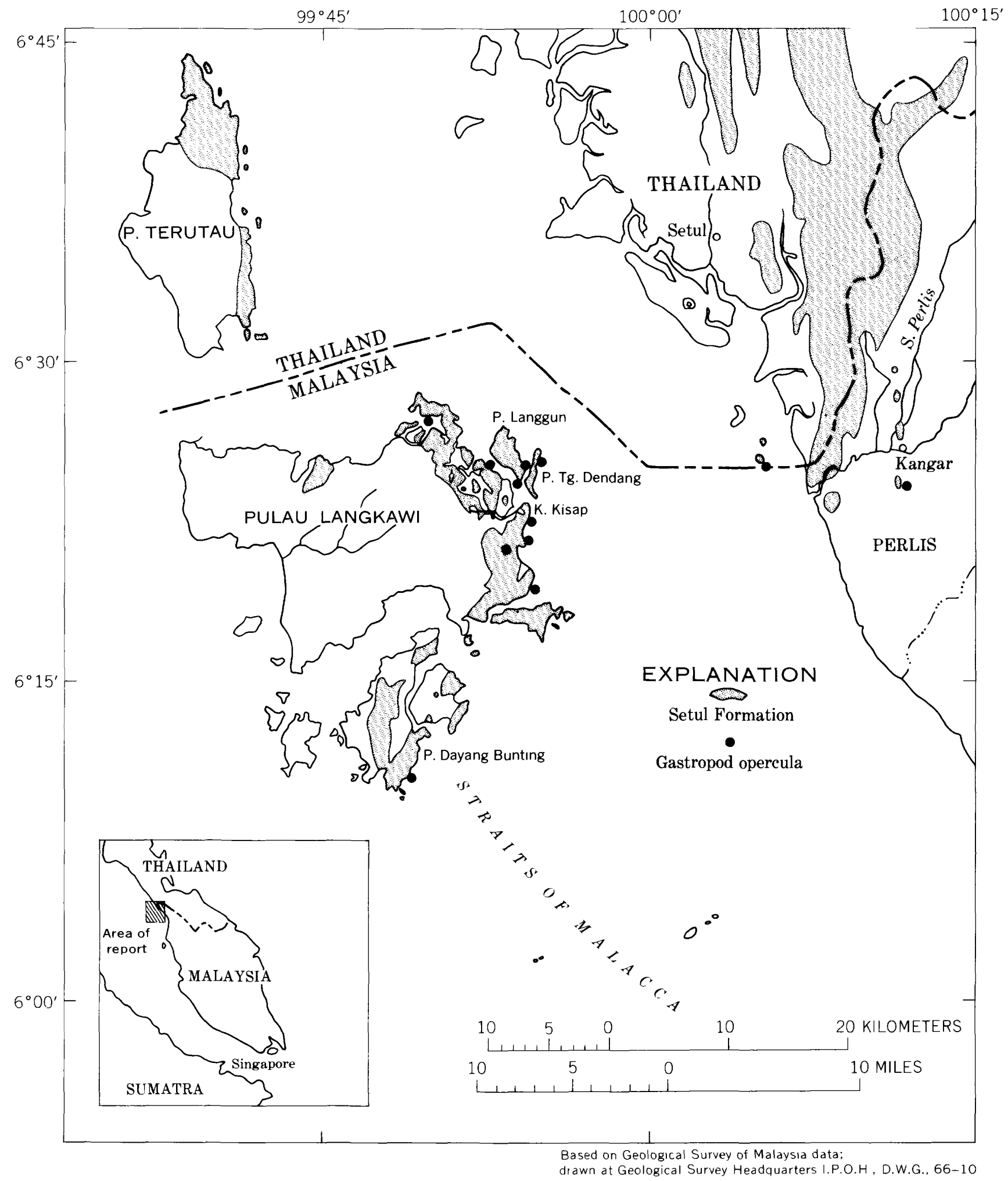

FigUre 1.-Map of northwest Malaysia and southwest Thailand showing distribution of the Setul Formation and local:ties at which gastropod opercula have been found. 
types of Barnesella leads us to believe that it is closely related to Malayaspira; indeed that name may prove to be a junior subjective synonym when Barnesella is better known. Except for its bearing on age determination, it is not appropriate to pursue this point further for it hinges on description of better specimens of Barnesella. Malayaspira had been considered by Kobayashi $(1958,1959)$ to be of early Middle Ordovician age.

A few specimens of a small compressed bellerophontacean with a narrow deep slit have also been recovered from the Boucot and Jones collections. They seem to be juvenile representatives of Salpingostoma. This genus, like Pararaphistoma, although not confined to the Baltic $B_{I I I}$ and the Vaginatenkalk, is certainly characteristic of that interval.

Thus, our reevaluation of the gastropods from Pulau Langgun strengthens Kobayashi's (1959) original suggestion that this part of the Setul Formation is late Early Ordovician. Several apparent anomalies in his determinations have been readily resolved by a study of the new collections.

Two pelecypod genera have also been obtained from the new collections. They include Ctenodonta (in the strict sense) and well-preserved specimens of Euchasma (John Pojeta, Jr. oral commun., July 1967). Euchasma has been reported only from rocks older than Middle Ordovician. One incomplete monoplacophoran has been recovered but it does not provide significant data on age relations.

Regarding the few cephalopods found in the Boucot collection, R. H. Flower (written commun., April 1966) wrote:

One of the specimens is a long slender siphuncle recalling: Clitendoceras (= Kirkoceras) which is known to me only in Demingian, Middle Canadian. It is anomalous in that the curvature is eccentric; the specimens might be a new form leading to the remarkable Escharendoceras (Canadian of New Mexico and Maryland) which has the section more askew. It is possible, however, if other fossils show distortion which is tectonic, that the eccentricity might not be organic. [It is likely that these fossils have been distorted.]

There is another fragment of a straight orthocone with apparently a central siphuncle. There is not enough to say what this is for certain. It could be Wolungoceras, known mainly from the Late Canadian of Manchuria, or less likely it might be one of the early Michelinoceratidae. In either case, I would expect this to have come from nothing in the Canadian below the Cassinian, and it suggests a materially younger Canadian age than does the other species. I say "suggest" in both cases, because surprises in ranges are still turning up in the cephalopods, but these are the limits of range in the present state of our knowledge.

Specimens obtained from the Richard Jones collection includes members of the Proterocomeroceratidae and a new genus possibly allied to the Bassleroceratidae. These further strengthen the age assignment of late Early Ordovician (R. H. Flower, oral commun., May 1967).

The only other specimens obtained at the locality are rare twig-shaped objects which could be silicified bryozoan colonies. The identified gastropods, cephalopods, and pelecypods suggest a late Ear'y Ordovician age. The possible presence of bryozoans reinforces the idea that the strata at this locality represent, at the oldest, a fairly late interval in the Early Ordovician.

Collateral evidence bearing on the age of this part of the Setul Formation comes from a second collection of silicified fossils, obtained from the east end of Pulau Langgun. This faunule consists almost exclusively of hundreds of brachiopods belonging to a new genus of late Early Ordovician aspect. (G. A. Cooper, oral commun., June 1966). Associated with the brachiopods are several opercula. Thase are flattened and roughly subtriangular, not at all like the elongate fibrous-textured opercula found at the south end of the island. Both kinds of opercula, however, are found in collections of fossils from residuum of the Odenville Limestone in Alabama.

\section{GEOLOGIC SETTING IN NORTH AMERICA}

Specimens pertinent to this study are gengraphically widely scattered. At no one place are they particularly abundant and, accordingly, thoir common characteristics have not been generally recognized heretofore.

The Odenville Limestone (Butts, 1926, p. 99-100) is a poorly known stratigraphic unit described as occurring above the Newala Limestone of Canadian age and below the Mosheim Limestone of Middle Ordovician age. Its only known exposure is the type locality, about one-third of a mile east of Odenville, Ala. At the time it was investigated by Butts, the formation, or at least its upper part, was exposed in a railway borrow pit. Pit operations coased at least half a century ago and the pit is virtually filled in and overgrown. One isolated block occurs in the pit area and perhaps 5 feet of the uppermost part of the formation is exposed in the nearby woods.

The only fossils reported from the Odenville Limestone were collected from soils directly above the Newala Limestone, in part near the type locality, but mainly in the Cahaba valley of Alabama. On the basis of the brachiopod assemblage found in Cahaba valley residuum (Ulrich and Coopor, 1938, pl. 58), the formation is generally dated as latest Canadian (Twenhofel and others, 1954). In 1966, C. W. Cressler and E. L. Yochelson failed in attempts to locate several of the Cahaba valley localitios which 
had produced the fossils described by Butts. They were able, however, to recover several specimens of the operculum of Maclurea? odenvillensis, as well as two fragmentary shells from the outcrop at the type locality. As a result, they demonstrated for the first time the rather curious fact that the fossil assumed to be most characteristic of the formation does actually occur in the formation. Accordingly, more reliance can be placed on the collections of isolated and residual Odenville fossils than has hitherto been the case.

The interval represented by the Odenville Limestone has not been reported in other areas of northwestern Alabama. Extensive mapping of Paleozoic sedimentary rocks by C. W. Cressler in adjacent northwestern Georgia, with particular emphasis on the Newala Limestone, has not demonstrated the occurrence of overlying Odenville Limestone which is also unknown along parallel strike belts in Tennessee. The Odenville Limestone is presumably the sole remaining erosional remnant representing the latest Canadian interval in the southern United States. Its precise relationship to the upper Lower Ordovician Black Rock Formation of northern Arkansas is unknown.

UTAH

Ross (1951) has made a detailed study of the Garden City Formation in northeastern Utah and southeastern Idaho. He divided the formation into 12 lettered zones from $A$ at the base to $L$ at the top; zone L is overlain by the Swan Peak Quartzite. Ross (1951, p. 31) concluded "that zone $J$ is very close to the Lower-Middle Ordovician boundary," though definitely in the Lower Ordovician.

Published faunal work by Ross was confined to the trilobites, though many brachiopods were also collected during the course of his investigation. At one locality in the Logan quadrangle, Utah, gastropod opercula were obtained; these are formally named and described below. Associated brachiopods include Diparelasma, Tritoechia, Syntophopsis, and Hesperonomia; the fauna is considered latest Early Ordovician. (R. J. Ross, Jr., written commun., April $1966)$.

No other occurrences of opercula are known from the Garden City Formation. Further west in the Ibex area of central Utah, other specimens were collected by L. F. Hintze and R. H. Flower from the Wahwah Limestone of Hintze (1951). Weathered specimens show the characteristic fibrous texture. The opercula are not silicificed and are too incomplete for specific identification but they are almost certainly conspecific with the material collected by Ross. Hintze (1952, p. 7-18) correlated the lower 130 feet of Wahwah Limestone at Ibex with zone $J$ of the Garden City Formation.

The upper part of the Garden City Formation and the Wahwah Limestone are probably equivalent to the Ninemile Formation in Nevada and southern California. No fibrous-structured opercula have been, to our knowledge, collected or reported frcm that unit.

\section{NEWFOUNDLAND}

Collections from the Cape Norman area at the extreme northern tip of the island and from Pcrt au Port along the southwestern coast may be pertinent to this study, even though the available material is scanty and poorly preserved. The two localities, 250 miles apart, are in a belt of rocks which has been subjected to complex structural dislocation (Rodgers and Neale, 1963). It is necessary to discuss these as two isolated occurrences, for though the general stratigraphic framework of the area has been known for many years (Schuchert and Dunbar, 1934), many significant details of correlation remain to be established.

The St. George Group is best known from the Port au Port peninsula to the west of Stevenville. The geology of the area was discussed by Schuchert and Dunbar (1934, p. 46-51) and has been mapped by Riley (1962). Riley (1962, p. 18) noted that the upper surface of the St. George is an "erosion surface of irregular relief" which is overlain disconformably by the Table Head Group of Middle Ordovician age.

Riley (1962, p. 64-67) reported Ceratopea keithi Ulrich from the upper part of his St. George section. This species is an excellent guide to the lower part of upper Lower Ordovician rocks (Yochelson and Bridge, 1957). Whittington re-collected in this area during the 1965 field season. Yochelson studied the species in two of Whittington's collections. These species are at variance with the species reported $\mathrm{ly}$ Riley. Riley's specimens may have been misidentified. Alternatively, local erosion might be the cause of at least part of the different interpretation, the upper formational surface being an unreliable datum plano. Riley's collections are not at the Geological Survey of Canada and it is not possible to resolve this apparent conflict in age determination.

The first Whittington collection (Geological Survey of Canada, colln. 73567) was obtained 100 yards northeast of The Gravels, Port au Port. Whittington suggested that it was obtained between beds 1- 6 of Riley (1962, section 1, p. 64). The rocks in this interval are about 80 feet thick and thought to $h$ ? no more than 150 feet below the top of the St. George Group. The collection contained specimens 
of the operculum of Ceratopea unguis Yochelson and Bridge; this is the youngest known species of Ceratopea and wherever it has been found in the United States it characterizes beds of latest Early Ordovician age.

Northwest of The Gravels, a second collection (GSC colln. 73567) was obtained from beds 50-80 feet below the top of the St. George Group. These beds were thought to be between beds $46-49$ of Riley (1962, section 2, p. 64-65). This collection yielded additional well-preserved light-gray silicified opercula of $C$. unguis. Fragments of a second operculum, apparently a slightly curved form, were also recovered; these have a reddish-gray hue. The fragments may be $C$. keithi, a species reported by Riley from beds both above and below this interval, but they are too incomplete for specific identification. The fragmentation and difference in color suggest reworking. In the United States, $C$. keithi and $C$. unguis have never been found associated; they mark distinct subdivisions within the late Early Ordovician.

The collection also includes silicified elongate fibrous opercula which are gray, but of a different hue than the specimens of $C$. unguis. The fibroustextured opercula do not preserve any of the outer surface; this is either the result of wear or of incomplete silicification. The amount of curvature shown by the opercula suggests similarity to the operculum of Maclurea? odenvillensis Butts; closer comparison is unwarranted. Because these curved fragments are rather long and moderately fragile, they were presumably in place rather than reworked from older beds.

The association is significant for it demonstrates that the fibrous texture is a fundamental feature, not simply a result of silicification. The silicified Ceratopea opercula have a smooth, rather fine texture, no different from specimens in dozens of other collections of sillicified Ceratopea. This occurrence also places the fibrous opercula within the stratigraphic framework based on Ceratopea. If this new operculum is associated with $C$. unguis, it is of latest Early Ordovician age. Even if it occurs as low as the zone of C. keithi, it is still limited to about the upper one-fourth of Early Ordovician time. Whittington and Kindle (1963) have assigned the lower part of the overlying Table Head Group to the Whiterock stage of earliest Middle Ordovician age. Therefore, if one allows for the maximum stratigraphic range, the fibrous form of operculum had an extremely short timespan.

Whittington (written commun., May 1966) obtained some fossils about 800 feet lower in the St.
George Group, approximately at the level of bed 36 or 37 of Riley (1962, section 2, p. 65), ard stated "Brachiopods and the trilobites Petigurus sp. and a bathyurid genus indicative of caudatus ( $\mathrm{P}$ illings) were collected. These suggest equivalence to unit $\mathrm{G}$ of the Cape Norman and Port au Choix sections in Newfoundland." This faunule is a principal tie between that area and Port au Port.

The stratigraphic detail in the Cape Norraan area is even less satisfactory than that at Port au Port and may, in fact, not be germane to this problem. Billings (1865, p. 243) noted "At Cape Norman, associated with $M$. oceana, the three forms of operculum figured above (figures 228-230) were found, evidently belonging to distinct species." Billings did not give formal names to these opercula, trough he stated "opercula, differing so widely from each other, prove that there are also many distinct species of Maclurea to which they belong. Accordingly at Cape Norman we find fragments of what appear to be forms different from those described above." $\mathrm{He}$ proposed three new species, Maclurea sylpha, $\boldsymbol{M}$. psyche, and $M$. rotundata, which he based on shells but he did not assign any of the opercula to a particular species. These three species were all reported as occurring in unit G of Logan, an interval of 400 feet within the St. George; no details are known of the distribution of any of these species within the interval.

Of the three species named by Billings, Maclurea sylpha is questionably transferred to the new genus described below. One cannot ignore the morphologic similarity between Maclurea sylpha, as it is currently known, and the shells from Malaysia. The assignment may be in error for the only kncwn shell is incomplete, has no associated operculum, and is found somewhat lower in the section than the stratigraphic distribution of the characteristic operculum in Alabama and Utah. Nevertheless, the Port au Port occurrence of the operculum, associated possibly with Ceratopea keithi, raises the possibility that this genus could occur in rocks slightly older than latest Early Ordovician.

For the sake of completeness, Maclurea rotundata should be mentioned. The two syntypes (GSC 611 and 611a) are wretched steinkerns; withont better topotype material further use of the name is unwarranted. Billings reported this species from Cape Norman, but the accompanying label indicates that the types are from Bonne Bay. In this area both Lower and Middle Ordovician strata are exposed (Schuchert and Dunbar, 1934, p. 28; Baird, 1960), so that one is also uncertain as to the stratigraphic position of this species. 
The placement of Maclurea psyche is uncertain, as the type or types cannot be located. The species was not illustrated and there is no justification for further use of the name until such time as topotype material can be described and illustrated.

The present status of the three Cape Norman opercula should be mentioned. The specimen shown in figure 228 (Billings, 1865) is the holotype of Ceratopea billingsi Yochelson (1964, p. 7-8); the specimen shown in figure 230 (Billings, 1865) is C. unguis Yochelson and Bridge. The third operculum shown in figure 229 (Billings, 1865) represents still another form which probably will be assigned to the family Macluritidae, but it is as distinct from the thickened, fibrous Teiichispira operculum as that form is from the platelike Maclurites operculum. This distinct form of operculum has also been collected by Whittington at Port au Choix, Newfoundland (GSC colln. 73568). It also occurs at Bartlett Bay Peninsula, Ellesmere Island (GSC colln. 47277). It has not been reported from other areas of Lower Ordovician rocks.

\section{SYSTEMATIC PALEONTOLOGY Superfamily MACLURITACEA Family MACLURITIDAE}

Discussion.-Representatives of the family Macluritidae are excellent guides to rocks of early Paleozoic age. Four genera and two subgenera, all restricted to the Ordovician, were placed in the family by Knight, Batten, and Yochelson (1960, p. I188-I189). The only post-Ordovician genus previously assigned to the Macluritidae (Knight and others, 1960, p. I189) is the Devonian Omphalocirrus. That genus has been reinvestigated and assigned to the Euomphalacea (Yochelson, 1966). Specimens assigned to the Macluritidae recently have been found in rocks of Late Cambrian age (G. F. Webers, oral commun., 1966).

The hyperstrophic coiling of the macluritaceans is atypical of most gastropods and necessarily presents problems in terminology. It seems appropriate to confine the term "depressed spire" to any downward inclination of the basal surface, such as that which characterizes Palliseria. The upper surface of the shell, in this family, is invariably an opening in which all earlier whorls can be seen. In this respect, it is most similar to an umbilicus, but the term pseudoumbilicus is inappropriate. Pseudoumbilicus is commonly used for a feature of the base in unrelated orthostrophically coiled groups. "Apical cavity" is the term proposed here for the opening, formed by the upward coiling of whorls, seen when the shell is placed in conventional American and
English orientation. Terminology for description of opercula follows that used for the opercula of Ceratopea (Yochelson and Bridge, 1957).

It is apparent that earlier casual speculations concerning macluritacean opercula (Yochelson and Bridge, 1957, p. 290) are incorrect. The operculum of the new genus described herein is so strikingly different from that of a typical Maclurites that it is difficult to see in retrospect how the "natural group" of Yochelson and Bridge was constructed. Unfortunately, the subjective tendency has been to lump Ordovician opercula simply because their common feature of calcification during life makes them potentially a part of the fossil record. Accumulating evidence permits the speculation that macluritacean opercula may be more sensitive indicators of biologic diversity and stratigraphic utility than the conchs themselves.

\section{Genus TEIICHISPIRA Yochelson and Jones, n. gen.}

Type species.—Teiichispira kobayashi, n. sp.

Description.-Slowly expanding hyperstrophic gastropods having a steeply inclined, moderately high outer whorl face, distinct sutures, and an elongate, curved, calcified operculum. Apical cavity deep with smooth, slightly arched walls. Outer whorl face steep except for rounded basal angulation where it curves strongly inward. Basal sutures distinct. Operculum elongate, slightly torted, with a sharply carinate upper surface; composed of elongate polygonal to rounded tubes.

Discussion.-Teiichispira is readily distinguished from Lecanospira by its higher spire and from Macluritella by its higher spire and by contact of whorls through all growth stages. Lecanospira and Macluritella are two of the four genera placed in the Macluritidae by Knight, Batten, and Yochelson (1960). The flattened base differentiates Teiichispira from the depressed spire of Palliseria (Yochelson, 1957).

Teiichispira is less readily distinguished from Maclurites, partly because the concept of Maclurites has been greatly expanded over the years to include almost any large hyperstrophic gastropod. Typical Maclurites shells are characterized by a more moderately inclined outer whorl face (fig. 2) and at least some species have a platelike operculum. Teiichispira shells expand at a slower rate than do true Maclurites. These criteria readily distinguish the tro genera. Application of these criteria to a more rigorous definition of Maclurites might result in reassignment of some of the pre-Middle Ordovician species assigned to that genus. However, investiga- 
tion of all Early Ordovician "Maclurites" is beyond the scope of this paper.

Two other recently named genera should be assigned to the family. Malayaspira (Kobayashi, 1958), of early Middle Ordovician age, is a relatively lowspired form, very closely related to Lecanospira (Barnesella) and is possibly a subjective synonym of that taxon. The Middle Ordovician Paramaclurites (Vostokova, 1964) is reported to have an oval growth plan. Its relationship to Maclurites is not yet known, but its low, sloping profile distinguishes it from Teiichispira.

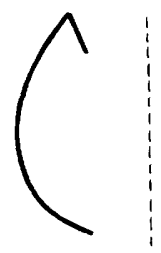

A

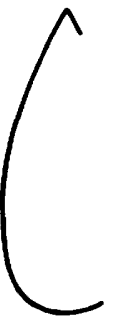

$D$

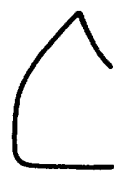

$B$
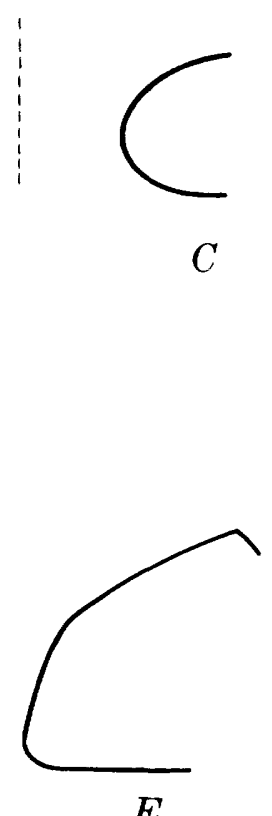

$E$
Figure 2.--Generalized outer whorl-face profiles of some macluritaceans: $A$, Teiichispira; $B$, Lecanospira ; $C$, Macluritella; $D$, Palliseria; $E$, Maclurites. Not to scale.

Teilchispira kobayashi Yochelson and Jones, n. sp.

Plate 1, figures 2-8

Lesueurilla(?) sp. undet., Kobayashi, 1959, p. 398, pl. 26, figs. $6 \mathrm{a}, \mathrm{b}$.

Description.-Hyperstrophic gastropods, very shallowly umbilicate; with a deep apical cavity, so that whorl profile is teardrop shaped in section, and with an elongate operculum closely adjusted to this whorl shape. Nucleus and early whorls unknown. Outer whorl face relatively high; body whorl embracing penultimate whorl at periphery; whorls expanding slowly; tangent angle of logarithmic spiral relatively high. Apical cavity deep, narrow; the angle of the walls near $35^{\circ}$. Apical sutures moderately shallow, penetrating only to periphery of succeeding whorl, quite sharp, V-shaped in profile, and narrow, so that each succeeding segment of the apical cavity wall is set back only a short distance. Whorl profile rising smoothly upward and slightly outward from apical suture and following a convex curve so slight that it appears to be nearly straight and inclined near $75^{\circ}$ from the horizontal; upper angulation sharp. Outer whorl face follows a gently convex curve, inclined outward to periphery above midwhorl, below which the face is inclined slightly inward to a point, quite low on the whorl, where the curvature, increases rapidly and approximates the arc of a circle, which produces a narrow, wellrounded juncture rather than a basal anculation. Outer part of basal whorl surface slightly rounded, but not flattened; lowest part of basal whorl surface moderately well rounded, and the inner part, extending to sutural contact with penultimate whorl, inclined slightly outward, but only moterately arched, so that basal surface is widely phaneromphalous with an umbilical angle of near $165^{\circ}$; basal sutures wide and shallow. Shell distinctly tlickened at upper angulation; cross section of inner surface is nearly parabolic. Growth lines unknown on inner surface and across upper angulation; opis thocline on outer whorl face, but curving abruptly to orthocline at periphery and proceeding straight to basal surface, there bending prosocline very slightly, thence continuing straight until the deepest part of suture is reached. Ornamented by widely spaced, elongate rugosities which follow the course of the faint growth lines; other ornament lacking.

Operculum elongated by thickening; strongly curved but little torted; roughly teardrop shaped in cross section; thin relative to height. Upper edge sharply angulated. Outer face smoothly curved but only slightly inflated from upper angulation to near basal surface, nearly vertical when basal surface is held horizontal, and with maximum thickness about halfway down the outer face. Juncture of outer face and basal surface well rounded, following up the arc of a small circle through about one-third of its circumference, to a slightly more abrupt, but still rounded junction with the inner face. Inner face curving upward and outward to near the midline, from which it then proceeds inward and upward to the angulation; the inner surface, as a whole, more inflated and much more strongly inclined along its upper half than the outer whorl face. Erpanding with a moderately large logarithmic curvature; with virtually no torsion, best shown by slight slope of upper angulation with the basal surface hc rizontal. Upper angulation projecting forward. Growth lines opisthocline at an angle near $120^{\circ}$ on the outer surface and particularly prominent on the lower part of the face and the basal surface where they are in- 
cised; with a wide shallow sinus at the juncture of the two faces and a narrower sinus between basal and inner surfaces, the course of the basal area follows an elongate sigmoid curve; growth lines obscure on the inner surface.

Opercular margins simple; attachment surface not known in detail ; anterior of operculum with a faint median groove most prominent near the basal margin. Opercular structure porous, consisting of many elongate tubes, their openings three to four times the thickness of the walls, each tube possibly with a polygonal rather than circular cross section.

Discussion.-There is always some degree of uncertainty in assigning a free fossil operculum to a shell because their association in life cannot be demonstrated. In this instance, the occurrence of shells and opercula is so convincing that virtually no question remains. The inner profile of the aperture and the edge of the operculum show an essentially perfect fit. The shells and opercula are present in nearly equal numbers, though many of each are fragmentary because of deformation of the rock. The specimens show no indication of wear and the assemblage does not show any arrangement within the matrix that might be expected from transportation.

The principal distinguishing characters of the shell of Teiichispira kobayashi seem to be the excedingly shallow umbilicus and the impressed basal sutures. In the character of the sutures, the species shows considerable similarity to Lesueurilla, as was suggested by Kobayashi (1959). Lesueurilla infundibulum (Koken), the type species, is characterized by a relatively low whorl, a relatively gently inclined upper whorl face, and correspondingly, a gently inward sloping upper surface that contrasts greatly with the deep apical pit of T. kobayashi. Further, in Lesueurilla the umbilicus is slightly deeper and the basal cross section of the whorls is slightly more rounded. However, the type species of Lesueurilla and Teiichispira are similar enough on the lower half of the whorl so that fragmentary specimens showing only these features would be difficult to distinguish with any degree of certainty.

The operculum is perhaps the most striking and distinguishing feature of T. kobayashi. It is likely that all species of the genus had a thickened and calcified operculum, but the possibility cannot be ruled out that, in some species, the operculum was not calcified. Current sorting and preservation make it unlikely that consistent occurrences of shell and operculum will be found. Opercula are common in the Early Ordovician gastropod genus Ceratopea, but shells are exceedingly rare (Yochelson and
Bridge, 1957). It can be argued that there would be less confusion in designating the distinctive op?rculum of Teiichispira as the holotype, as was done in Ceratopea. This procedure is not followed hore because of the presumed association of shell and operculum has such a high degree of probability.

The operculum of Teiichispira mimics that of Ceratopea in size, though most specimens are somewhat larger than the average specimen of Ceratorea. There is a superficial resemblance in shape, but the angulation of the Teiichispira operculum is ventral, and the sides are little inflated. In the Ceratopea operculum, the carina, or angulation, is at the juncture of upper and lower surfaces and the orerculum is generally more rounded in profile. Most characteristically, Teiichispira opercula are composed of rods and show a "honeycomb" texture, whereas Ceratopea opercula appear more like thickened shell matter deposited in layers. Comparisor of specific features of the operculum are discussed in connection with other species of Teiichispira.

Numbered specimens.-Holotype, USNM 159947; figured paratypes, USNM 159948-159952; unfigured paratypes, USNM 159953 (more than 50 specimens).

Occurrence.-Setul Formation. South point of Pulau Langgun, Langkawi Islands, Malaysia. Other areas in northwest Malaysia and adjacent Thailand.

\section{Teiichispira odenvillensis (Butts) \\ Plate 2, figures 6-9}

Machurea? odenvillensis Butts, 1926, pl. 18, fig. 26 and explanation.

Description.-Hyperstrophically coiled macluritacean shells with a flattened base and a fibrous-textured operculum bearing a small prong on the lower part of the attachment surface. Shell hyperstrophically coiled; nucleus, and more mature parts unknown. Basal surface generally flat but witr a suggestion of slight upward tilting in more mature stages; basal sutures distinct, though not impressed, and individual whorls very slightly convex in rrofile, rather than flattened. Outer whorl face seemingly inclined at an angle of more than $70^{\circ}$ to the basal whorl surface and proceeding straight for most of its width, curving inward slightly at the upper quarter of the surface. Upper angulation share in early growth stages. Apical cavity prominent, not known in detail, but with a suggestion that the inner wall curves gently inward for most of its length and steeply downward near the base; apical sutures unknown.

Operculum wide and relatively low; cross section nearly triangular. Inner opercular surface divided in two segments; one segment short and well 
rounded, merging into the basal surface below and into the second segment above. This second segment, a long gently inclined surface which is the most prominent part of the operculum, terminates at upper angulation. Angulation wide but fairly sharp, its sides forming an angle near $70^{\circ}$. Outer opercular face essentially straight and seemingly nearly vertical downward from the angulation to the periphery, which is extremely low on the operculum; below periphery, the side curving strongly inward to a broad, very gently convex basal surface unmarked by a sharp angulation at either edge. Upper margin of attachment gently convex, but projecting strongly forward so that the inner margin forms an angle of $40^{\circ}$ with the horizontal and the outer margin forms an angle near $55^{\circ}$. Attachment surface excavated slightly below the level of all margins except the basal margin so that its surface forms a broad shallow basin; a prong extends outward from this surface and is located just above the basal margin and close to the lower curved part of the inner margin. Operculum composed of polygonal tubules.

Discussion.-The shell of Teiichispira odenvillensis (Butts) is poorly known from two fragments, collected at the type locality, which have weathered in partial relief from the limestone. The only meaningful measurement which may be taken suggests a whorl height of about 8 millimeters at a diameter of about $12 \mathrm{~mm}$; one specimen must have grown to more than $75 \mathrm{~mm}$ in width during life. The flattened basal surface and nonimpressed basal sutures distinguish $T$. odenvillensis from $T$. kobayashi. The inner surface of the inner whorl is more inclined and slightly more curved in T.? sylpha. No comparison of shell can be made to T. rossi.

A second kind of operculum has been found in the Odenville fauna in the Cahaba valley of Alabama and is mentioned at the end of this discussion. It is possible that the shell fragments found at Odenville are associated with that form and not with Teiichispira, though those opercula do not seem to fit the shell fragments quite as well as do the opercula of $T$. odenvillensis.

The operculum of this species is far better known than the shell. The broad low shape distinguishes this from the opercula of $T$. kobayashi and T. rossi. There is also a slight difference in the angle of curvature of the three opercula with that of $T$. odenvillensis having the most rapid coiling. Perhaps the easiest feature to observe is the significantly greater width of this form.

An even more important opercular feature, but one not preserved on all specimens, is the $\mathrm{p}$ rong on the attachment surface (fig. $3 A$ ). The pit on the equivalent surface in the operculum of $T$. rossi contrasts with this feature (fig. $3 B$ ). Almost certainly both were used for attachment of a major rotractor muscle. The attachment surface on opercula of $T$. kobayashi is not known because all specimen" appear to be broken at the anterior.

It is difficult to evaluate the significance of these two modes of muscle attachment. Probably it is a valid specific difference, but whether it also implies generic level differences is a judgment which must await discovery of additional species and more adequate shell material of $T$. odenvillensis. By way of analogy, it is likely that Ceratopea could be divided into several genera, simply on the basis of what is known of the opercular shapes (Yochel on and Bridge, 1957), but in both that case and this one, it seemed better to follow a conservative texonomic approach.
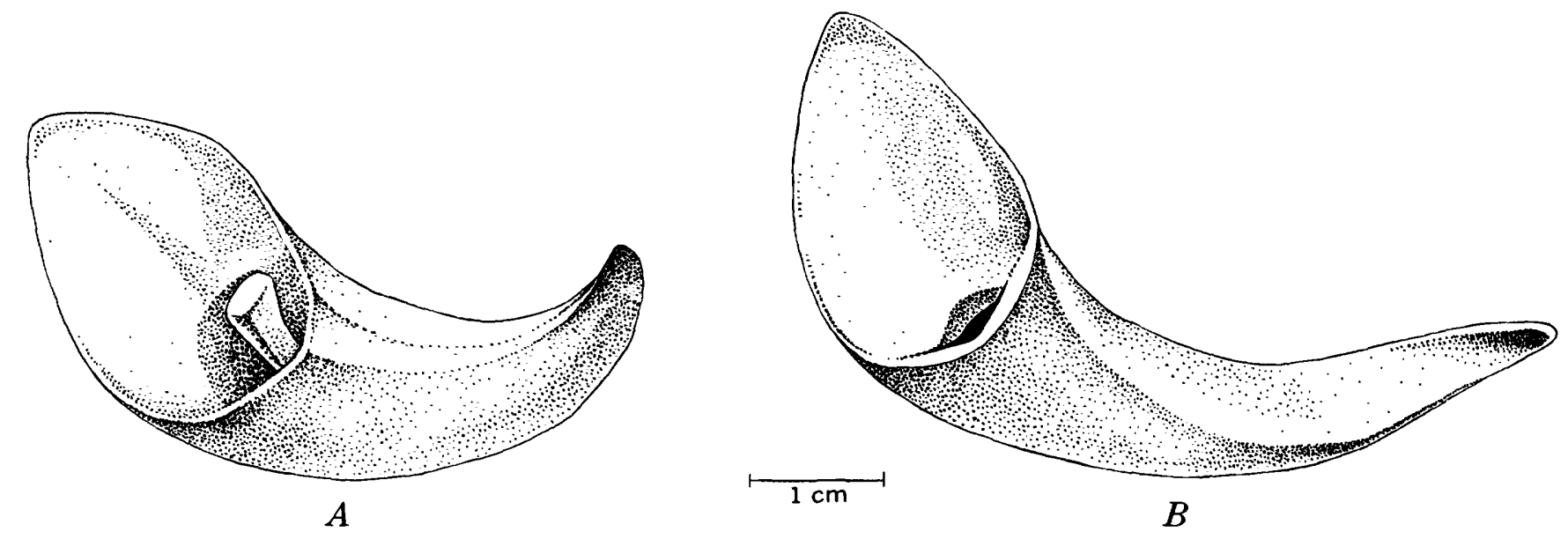

Figure 3.--Sketches of the opercular attachment surface.

$A$, Teïchispira odenvillensis showing a prong; $B, T$. rossi showing a pit. 
The operculum of Maclurites logani (Salter) (see Salter, 1859, pl. 1) is characterized by a prominent prong near the juncture of the inner and basal opercular margins, at virtually the same location as on T. odenvillensis. There is a second thickened and roughened area near the juncture of the inner and outer margins. From this, it has been concluded that Maclurites possessed two retractor muscles (Knight, 1952, p. 40).

Although the opercula of two of the three known species of Teiichispira show only one retractor muscle attachment, one need not place much significance on this feature. First, the elongate operculum is quite different from the more typical platelike Maclurites operculum; perhaps only one major retractor was needed. Second, and far more important, observation of the second muscle attachment in Maclurites opercula is governed in large measure by preservation and ontogenetic stage, for small opercula do not show this second area. The distinctly eccentric, rather than central, position of the muscle prong on the operculum of $T$. odenvillensis tends to support the view that a second smaller muscle may have been present. Its small size, combined with the fibrous texture of the surface, would obscure any indication of its presence. It is clearly inadvisable at this time to suggest that Teiichispira might represent a family-level taxon distinct from Maclurites.

Even though most Maclurites opercula are platelike, the operculum of $M$. profundus (Butts) from the Lenoir Limestone mimics the operculum of $T$. odenvillensis. The best specimens were also obtained near Odenville, Ala. (Butts, 1926, pl. 21). The similarity in shape is so close that E. O. Ulrich (USNM specimen label) originally considered the outcrop producing them to be Beekmantown. Even though these opercula are elongate, they are slightly wider, more strongly curved, and somewhat more twisted than opercula of $T$. odenvillensis. The attachment surface is deeper and smoother and the prong more spatulate and larger. Most importantly, opercula of $M$. profundus lack the prominent fibrous texture so characteristic of Teiichispira opercula.

It may be appropriate to mention that the other form of Early Ordovician operculum found with that of $T$. odenvillensis also has a widespread distribution. This operculum is relatively short and more platelike than that of Teiichispira; it is somewhat more triangular in outline than the typical Maclurites operculum. As discussed on page B10, a platelike operculum occurs in the Langkawi Islands along with late Early Ordovician brachiopods. This operculum is congeneric with that which occurs in residuum collections of Odenville fossils and is ill' 1strated on plate 2, figure 1, for comparison to the Alabama form (plate 2, fig. 2).

This same form of platelike operculum may c.lso occur in unit C-1 (Cloud and Barnes, 1948 p. 361369 ), at the top of the El Paso Limestone sectior in Texas and New Mexico, but material is not adequate for specific identification (R. H. Flower, written commun., June 1967). No shells are known with any of these occurrences and it is not appropriate to pursue their morphology and biostratigraphy further at this time. They are noted here as a further indication of the wide diversity of opercular shapes to be found within the Macluritacea. Material suggestive of Teiichispira opercula has also been found by Flower in the upper part of the El Paso Limestone, but it is also too fragmentary to be discussed.

Butts (1926, p. 100, plate explanation) did not specifically designate a type specimen of Maclurea? odenvillensis. It seems reasonable, however, to treat his figured specimen as the holotype, and to assign paratype status to all other specimens collected by him from the type locality.

Numbered specimens.--Holotype, USNM 71465; figured partypes, USNM 159960, 159961; unfigured paratypes, USNM 159962 (139 specimens); hypotype, USNM 159963.

Occurrence.-Odenville Limestone. USGS loc. $320 \mathrm{v}$ (green), 1 mile northeast of Gary, Ala.; US GS loc. 362i (green), $1 / 4$ to $1 / 2$ mile southwest of New Hope Church and 7 miles north of Pelham, Ala.; USGS loc. 445s (green), borrowing grounds on north side of Seaboard Railroad track, $1 / 2$ mile east of Odenville, Ala.; USGS loc. 474c (green), Cahaba valley, about 8 miles southwest of Leeds, Ala.; USGS loc. 6148-CO, possible re-collection from outcrop of USGS loc. $445 \mathrm{~s}$. All localities except 6148$\mathrm{CO}$ are cataloged in U.S. National Museum old "green" series.

\section{Teiichispira rossi Yochelson and Jones, n. sp}

Plate 2, figures 3-5

Description.-Operculum greatly elongated by thickening and with a prominent pit in the attachment surface. Operculum cross section moderately wide; when placed upon the basal surface, the profile of the inner opercular face forms a simple line proceeding straight upward at an angle of near $50^{\circ}$ to the upper angulation; upper angulation not known in detail but probably bluntly rounded, rather than sharp, its two sides forming an angle of near $65^{\circ}$; outer opercular face below angulation inclined smoothly downward and outward at angle near $15^{\circ}$ 
from the vertical with virtually no curvature until the periphery which is located approximately at the midpoint of the outer face; below periphery, the outer face curves strongly inward for the upper part of its course, the curvature gradually flattens downward but without any clear distinction between the outer and basal surfaces; basal surface distinctly flattened only near its inner edge and terminates at a sharp inner angulation. Operculum elongated by thickening, strongly curved and completing almost half a whorl at maturity; with virtually no torsion. Upper point of operculum protrudes distinctly forward of lower part so that the apertural margin of the inner surface forms an angle of $60^{\circ}$ with the basal angulation; precise course of outer margin unknown; growth lines unknown. Attachment surface bears a deep pit; the lower edge of this pit follows the basal surface of the operculum and the center occupies a position about one-third of the way between the basal surface and upper angulation; the pit is closer to the inner surface than to the outer, so that its walls give a modified triangular shape rather than circular.

Shell unknown.

Discussion.-WThis species is known from several dozen silicified opercula, most of which were recovered from one block of limestone. In spite of the relatively large number of specimens, few are well preserved. They are instructive in showing the various modifications which these fossils may undergo after death. Almost all the opercula are broken at the anterior along one of the growth increments, and thus no indication of the prominent pit is given. Individual "fibers" tend to be lost from the various surfaces so that many of the specimens are subrounded in cross section with no indication of an upper angulation and only the slightest suggestion of a basal angulation.

Although the shape of the operculum is a reflection of the shape of the inner surface of the shall aperture, it is appropriate to confine comparisons to the opercula themselves.

The opercula of $T$. rossi and T. kobayashi are similar in shape; both are relatively high and relatively narrow. The operculum of $T$. rossi expands following a slightly less pronounced logarithmic curve and correspondingly appears longer, or more thickened, than the operculum of T. kobayashi. The inner opercular surface is less strongly curved in $T$. rossi. When both are placed on their basal surface, the upper angulation is more central and the outer face more curved in $T$. rossi than in $T$. kobayashi; the upper angulation is fairly close to the periphery in the operculum of T. kobayashi. There is no distinct basal angulation in T. kobayashi.

These two opercula are quite different in detail from that of $T$. odenvillensis. That form is much lower and much wider so that the inner surface is very long and prominent. The basal surface is relatively short and a specimen placed on this surface is unstable. The angle of logarithmic coiling is larger so that it coils more rapidly. Finally, it is characterized by a prong on the attachment surface in contrast to the prominent pit in the operculum of $T$. rossi.

Numbered specimens.-Holotype, USNM 159956; figured paratypes, USNM 159957-159958; unfigured paratypes, USNM 159959 (43 specimens).

Occurrences.-USGS loc. D208c-CO, 147 feet below the top of the Garden City Formation. Collected on a ridge along the south side of Blind Hollow, SE $1 / 2$ NW $1 / 4$ sec. 27 , T. 13 N., R. 2 E., Logan quadrangle, Utah.

\section{Teiichispira? sylpha (Billings)}

Plate 1, figure 1

Maclurea sylpha Billings, 1865, p. 244.

Description.-A flat-based macluritacean with a relatively high and steeply inclined outer whorl face. Hyperstrophically coiled with a prominent apical cavity; nucleus and early growth stages unknown. Basal surface flattened; basal whorl surface flat except at the edge of the inner suture where there is an obscure indentation; sutures not impressed. Whorl profile not representing a simple geometric figure; basal surface flat, turning upward abruptly to a basal angulation; outer whorl face above angulation proceeds strongly upward and is inclined inward so that the side forms an angle of approximstely $65^{\circ}$ with the base, this outer face gently conver; upper edge a fairly sharp angulation, slightly thiclened at the crest; inner whorl face also follows a slightly convex curve of the same general inclination as that of the outer face for the upper one-third of its length, so that this part of the profile is shaped like an arrowhead from the crest to the point of contact with the penultimate whorl; below contact of suture the inner whorl face turns abruptly outward and follows a convex curvature similar to that of the outer whorl face. Apical cavity narrow and deep, with an angle of near $70^{\circ}$ pit walls little curved and stepped back at sutures only for the width of the upper angulation; sutures not impressed.

Operculum unknown.

Discussion.-The type and only known specimen is a well silicified but quite incomplete specinen. The 
only significant measurement which can be taken gives a height of $14.2 \mathrm{~mm}$ where the width is 21.2 $\mathrm{mm}$. A fragment of the next whorl is preserved, but it is impossible to estimate the size of a mature individual.

There are several reasons to question the generic placement of this taxon. First, it occurs in rocks that may be somewhat older than those in which other species of the genus have been found. Second, the distinctive operculum is not known with this shell. Third, the species is based on scanty and incomplete material.

In spite of the fragmentary nature of the type, some valid comparisons can be made with other species. The flattened basal whorls of Teiichispira? sylpha are similar to those of $T$. odenvillensis and unlike the arched basal whorls of T. kobayashi. The outer whorl profile, as reflected on the inner body whorl, is relatively high and distinctly arched. In $T$. odenvillensis, this profile is much lower and is virtually straight. In $T$. kobayashi, the whorl is relatively high and curvature is intermediate between that of the other two species mentioned. No comparison can be made to $T$. rossi.

Numbered specimen.-Holotype, GSC 613.

Occurrence. - "Cape Norman, Newfoundland" (Billings, 1865), in unit $\mathrm{G}$ of Logan.

\section{REFERENCES CITED}

Baird, D. M., 1960, Geology, Sandy Lake (west half), Newfoundland: Canada Geol. Survey Prelim. Ser. Map 471959.

Billings, Elkanah, 1865, Palaeozoic fossils, volume 1: Canada Geol. Survey, $426 \mathrm{p}$.

Bridge, Josiah, and Cloud, P. E., Jr., 1947, New gastropods and trilobites critical in the correlation of Lower Ordovician rocks: Am. Jour. Sci., v. 245, p. 545-559, pls. $1,2$.

Butts, Charles, 1926, The Paleozoic rocks in Geology of Alabama: Alabama Geol. Survey, Spec. Rept. 14, p. 41-230, pls. 3-76.

Cloud, P. E., Jr., and Barnes, V. E., 1948, The Ellenburger group of central Texas: Texas Univ., Bur. Econ. Geology Pub. 4621, 473 p., 45 pls.

Grabau, A. W., 1924, Stratigraphy of China, Pt. 1: Peking, China Geol. Survey, 528 p.

Hintze, L. F., 1951, Lower Ordovician detailed stratigraphic section for western Utah: Utah Geol. Mineralog. Survey Bull. 39, 99 p.

- 1952, Lower Ordovician trilobites from western Utah and eastern Nevada: Utah Geol. Mineralog. Survey Bull. 48, 249 p., 28 pls.

Jaanusson, Valdar, 1960, Graptoloids from the Ontikan and
Viruan (Ordov.) limestones of Estonia and Sweden: Uppsala Univ., Geol. Inst. Bull., v. 38, pt. 3-4, p. 289362 , pls. $1-5$.

Jones, C. R., Gobbett, D. J., and Kobayashi, Teiichi, 1966, Summary of fossil records in Malaya and Singapore 1900-1965: Geology and paleontology of Southeast A sia, v. 2 , p. $309-359$.

Knight, J. B., 1952, Primitive fossil gastropods and their bearing on gastropod classification: Smithsonian $\mathbf{M r}^{\mathrm{r}} \mathrm{isc}$. Colln. v. 117, no. 13, 56 p., 2 pls.

Knight, J. B., Batten, R. L., and Yochelson, E. L., 1960, [Descriptions of Paleozoic gastropods] in Moore, R. C., ed., Treatise on invertebrate paleontology, Part I, Mollusca 1: New York and Lawrence, Kans., Geol. Soc. America and p. I169-I331.

Kobayashi, Teiichi, 1958, Some Ordovician fossils of the Thailand-Malayan borderland: Japanese Jour. Geo'ngy and Geography, v. 29, no. 4, p. 223-231, pl. 17.

1959, On some Ordovician fossils from northern Malaya and her adjacence: Tokyo Univ., Fac. Sci. Jour., sec. 2, v. 11, pt. 4, p. 387-407, pl. 24-27.

Riley, G. C., 1962, Stephenville map-area, Newfoundlend: Canada Geol. Survey, Mem. 323, 72 p., 1 pl.

Rodgers, John, and Neale, E. R. W., 1963, Possible "Taconic" Klippen in western Newfoundland: Am. Jour. Sci., v. 261, p. 713-730.

Ross, R. J., Jr., 1951, Stratigraphy of the Garden City Formation in northeastern Utah, and its trilobite faunas: Yale Univ., Peabody Mus. Nat. History Bull. 6, 161. p., 36 pls.

Salter, J. W., 1859, Figures and descriptions of Canadian organic remains, Decade 1: Ottawa, Canada Geol. Survey, $47 \mathrm{p} ., 10 \mathrm{pls}$.

Schuchert, Charles, and Dunbar, C. O., 1934, Stratigraphy of western Newfoundland: Geol. Soc. America Mem. 1, 123 p., 11 pls.

Twenhofel, W. H., chm., and others, 1954, Correlation of the Ordovician formations of North America: Geol. Soc. America Bull., v. 65, no. 3, p. 247-298.

Ulrich, E. O., and Cooper, G. A., 1938, Ozarkian and Canadian Brachiopoda: Geol. Soc. America Spec. Paper 13, 323 p., $58 \mathrm{pls}$.

Vostokova, V. A., 1964, Gastropody ordovikskikh otlozrenii Severo-Vostoka SSSR [Gastropods of the Ordovician deposits of northeast USSR]: Nauchno-issledovate'ski Institut Geologii Arktiki, Uchenye Zapiski, Paloontologiya i Biostratigrafiya, no. 5, p. 57-77, pls. 1-4.

Whittington, H. B., and Kindle, C. H., 1963, Middle Orc'ovician Table Head Formation, western Newfoundland: Geol. Soc. America Bull., v. 74, p. 745-758, pls. 1, 2.

Yochelson, E. L., 1957, Notes on the gastropod Palliseria, robusta Wilson: Jour. Paleontology, v. 31, p. 648-650.

1964, The Early Ordovician gastropod Ceratopea from East Greenland: Medd. Gronland, v. 164, no. 7, 12 p., 1 pl. 1966, A reinvestigation of the Middle Devonian gastropods Arctomphalus and Omphalocirrus: Norsk Polar:nst. Arbok 1965, p. 37-48, 2 pls.

Yochelson, E. L., and Bridge, Josiah, 1957, The Lower Orcovician gastropod Ceratopea: U.S. Geol. Survey Prof. Paper 294-H, p. 281-303, pls. 35-38. 



\section{INDEX}

[Italic page numbers indicate major references]

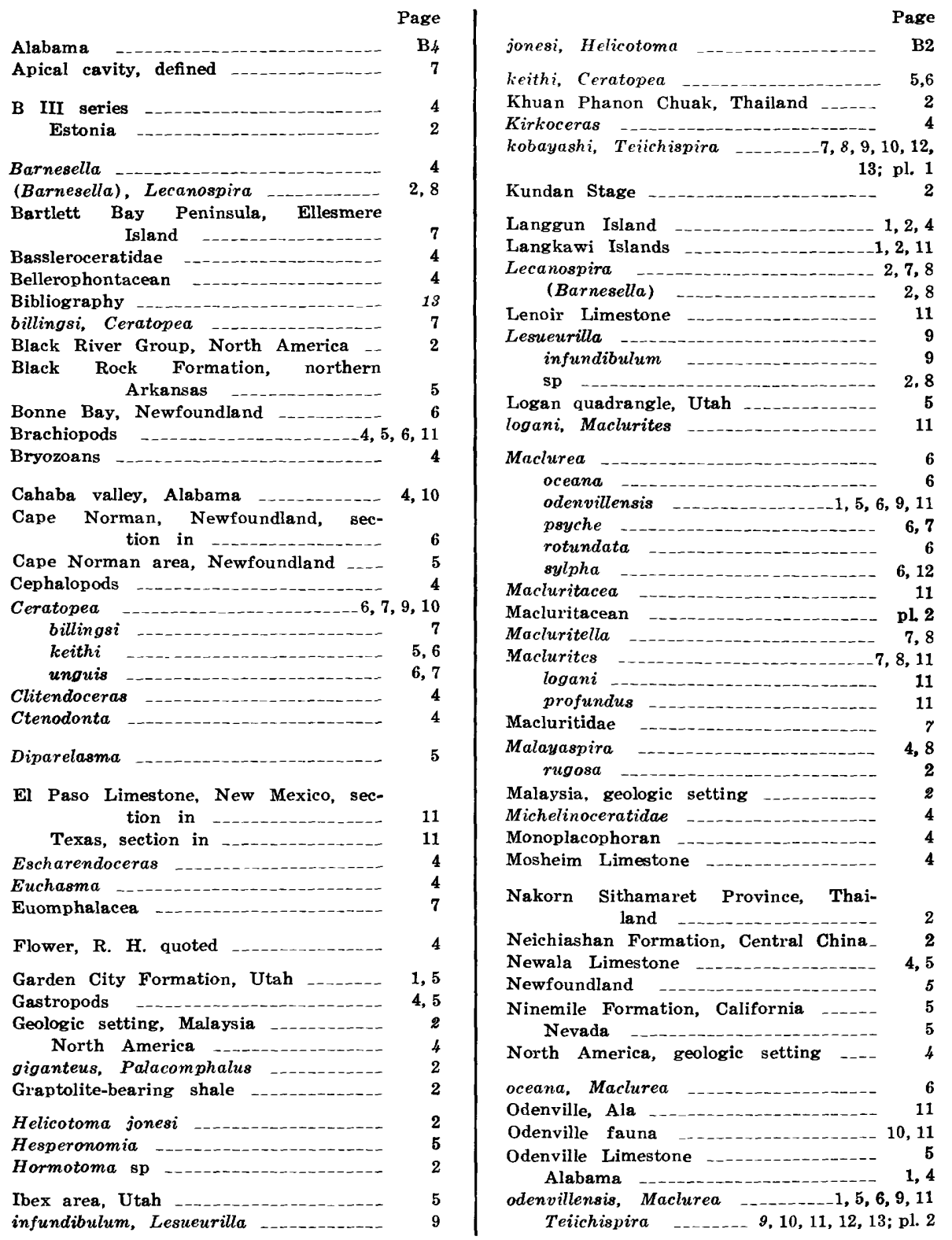

Page
Omphalocirrus

Orthoceras Limestone, Sweden

Palaeomphalus giganteus -

Palliseria _- 7,8

Paramaclurites

Pararaphistoma _..._. 2,4

Pelecypods _. 4

Perlis, State of - 2

Petigurus sp -...-..- 6

Port au Choix, Newfoundland

Newfoundland, section in 6

Port au Port, Newfoundland _.._._ 5, 6

profundus, Maclurites _.... 11

Proterocomeroceratidae -_- 4

psyche, Maclurea _. 6,7

Pulau Langgun _._._._._._._._._._. 1, 4

Pulau Tikus -... 1

Robsonoceras _......... 2

rossi, Teiichispira ____. 10, 11, 12, 13 ; pl. 2

rotundata, Maclurea

rugosa, Malayaspira

St. George Group, Newfoundland _-_ 5, 6

Salpingostoma

Setul Formation, northwest Malaysia $1,2,4$

Swan Peak Quartzite _... 5

sylpha, Maclurea _._._. 6, 12

Teiichispira

Syntophopsis _.... 5

Systematic paleontology _... 7

Table Head Group, Newfoundland - 5,6

kobayashi ___ $7,8,9,10,12,18 ; \mathrm{pl} .1$

odenvillensis __._._. $9,10,11,12,13$; pl. 2

rossi ___

sylpha _..._.

The Gravels, Port au Port, Newfound-

land -... 5

Trilobites

Tritoechia

unguis, Ceratopea 6,7

Utah

Vaginatenkalk

Baltic provinces, U.S.S.R

Wahwah Limestone, Utah

$\begin{array}{ll}\text { Whiterock stage } & 6 \\ \text { Wolungoceras } & \end{array}$ 

PLATES 1, 2 


\section{PLATE 1}

FigUre 1. Teiichispira? sylpha (Billings) (p. B12) from unit G of Quebec Group, Cape Norman, Newfoundland, GSC 613, $\times 1$.

a. Basal view.

b. Oblique side view.

c. Top view.

2-8. Teiichispira kobayashi Yochelson and Jones, new species (p. B8) from the Setul Formation, south point of Pulau Langgun, Malaysia.

2. Paratype, juvenile operculum, USNM $159948, \times 3$.

a. Upper surface showing carina.

b. Concave inner surface.

c. Attachment surface.

3. Holotype, USNM $159947, \times 1$.

a. Very slightly oblique view of attachment surface.

b. Convex outer surface.

c. Concave inner surface.

d. Upper surface showing carina.

e. Basal surface, very slightly oblique to emphasize growth lines.

4. Paratype, intermediate-sized operculum, USNM $159949, \times 2$.

a. Basal surface.

b. Attachment surface.

c. Concave inner surface.

d. Oblique basal surface.

e. Upper surface showing carina.

5. Paratype shell, USNM 159950, $\times 1$. This shell and the following ones are slightly distorted; tl a distortion is most obvious in side views of the specimens.

a. Top view.

b. Basal view.

c. Side view.

d. Cross sections.

6. Photograph of the outcrop showing the proximity of an operculum (lower center) to two shells $\times 1$.

7. Cross section of a paratype shell, USNM $159951, \times 1$.

8. Oblique top view of a broken paratype shell, USNM $159952, \times 1$. 

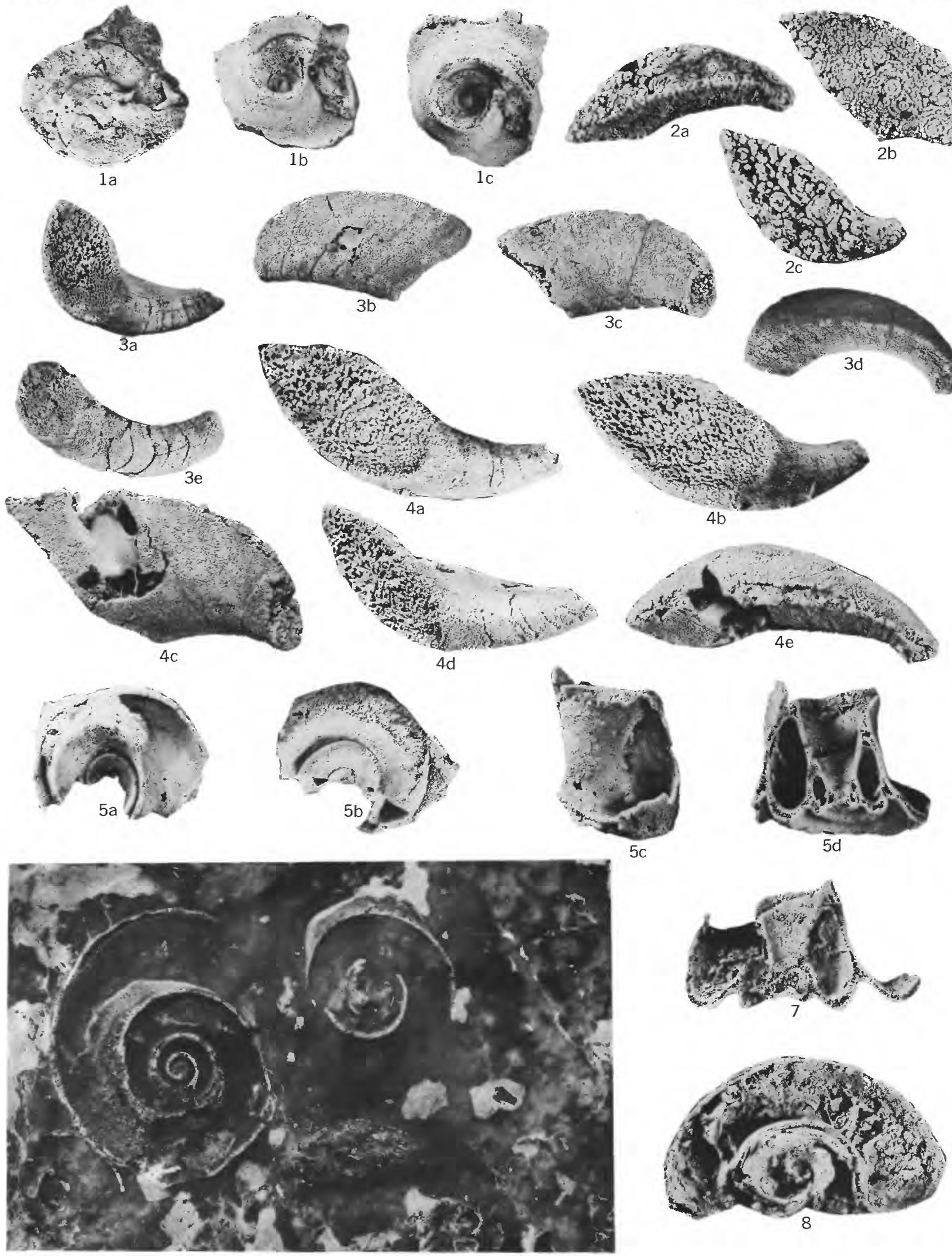

6

TEIICHISPIRA? SYLPHA (BILLINGS) AND T. KOBAYASHI YOCHELSON AND JONES 


\section{PLATE 2}

FIGURE 1. Operculum of unnamed macluritacean from the Setul Formation at the east end of Pulau Langgun, Malaysia, USNM $159954, \times 1 \frac{11}{2}$.

a. Exterior view.

b. Interior view.

c. View along carina.

2. Operculum of unnamed malcluritacean from the Odenville Limestone at USGS loc. 362i, 1/4-1/2 mile southwest of New Hope Church and 7 miles north of Pelham, Ala., USNM 159955, $\times 1$.

a. View along carina.

b. Exterior view.

c. Interior view.

3-5. Teiichispira rossi Yochelson and Jones, new species (p. B11) from the Garden City Formation at USGS loc. D208cCO, SE $1 / 2, \mathrm{NW}^{1 / 4}, \mathrm{SW}^{1 / 1} / 4$, sec. 27 , T. 13 N., R. 2 E., Logan quadrangle, Utah.

3. Paratype, worn operculum, USNM 159957, $\times 2$.

a. Upper surface.

b. Concave inner surface.

4. Paratype, broken operculum, USNM 159958, $\times 1$.

a. Attachment surface.

b. Convex outer surface tipped obliquely to show carina.

5. Holotype, USNM 159956, $\times 1$.

a. Upper surface.

b. Concave inner surface.

c. Basal surface tipped obliquely to show carina.

d. Attachment surface showing pit.

e. Convex outer surface.

6-8. Teiichispira odenvillensis (Butts) (p. B9) opercula from the Odenville Limestone at USGS loc. 362i, 1/4-1/2 mile southwest of New Hope Church and 7 miles north of Pelham, Ala.

6. Paratype, USNM $159960, \times 1$.

a. Upper surface.

b. Convex outer surface.

c. Basal surface.

d. Concave inner surface.

e. Attachment surface showing prong.

7. Basal view of holotype, USNM $71465, \times 1$.

8. Paratype, broken, USNM 159961, $\times 1$.

a. Attachment surface.

b. View of inner side showing growth lines.

9. Teïchispira odenvillensis (Butts), shell fragment from the Odenville Limestone at USGS loc. 6148-CO, small outcrop on north side of Seaboard Railroad track, 1/2 mile east of Odenville, Ala., hypotype, USNM 159963.

a. Top view, $\times 2$.

b. Side view, $\times 2$.

c. Oblique basal view, $\times 1 \frac{1 / 2}{}$. 

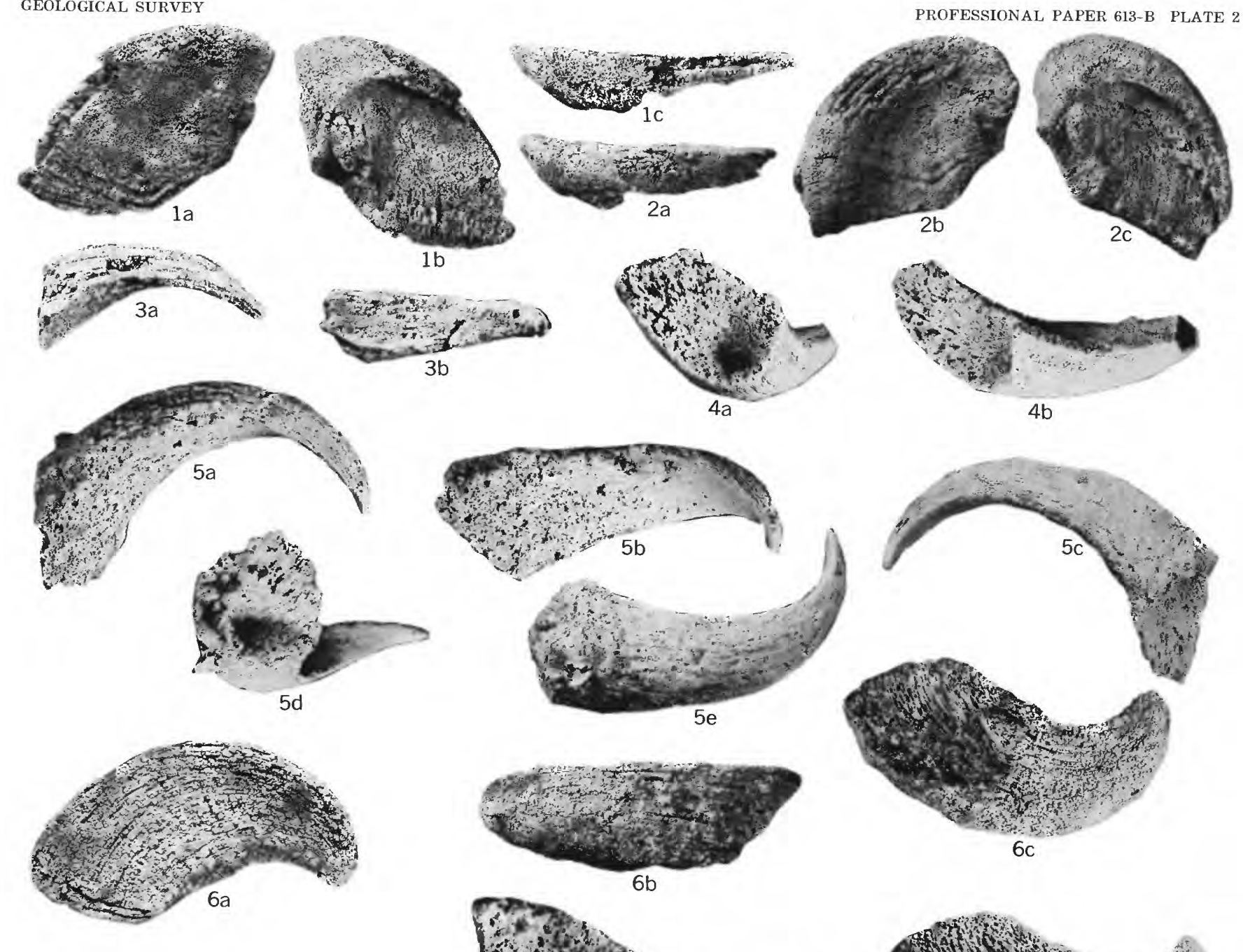

$6 \mathrm{~b}$
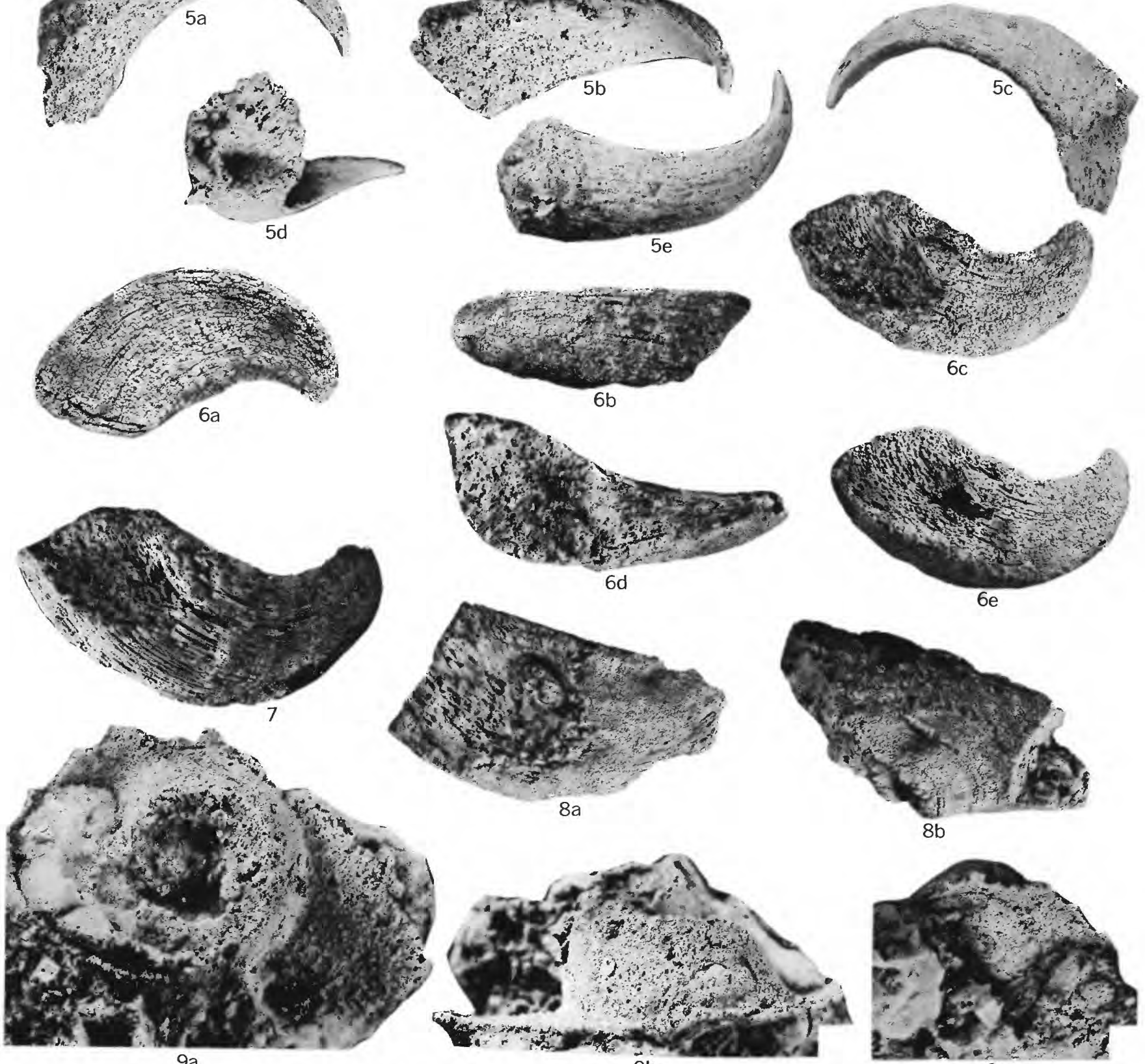

$9 \mathrm{~b}$

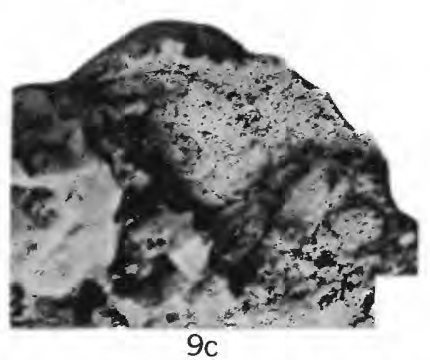

TEIICHISPIRA ROSSI YOCHELSON AND JONES, T. ODENVILLENSIS (BUTTS), AND OPERCULA OF UNNAMED MACLURITACEANS 